\title{
A Contextualized Enamel Growth Rate and Thickness Data Set Collected from British Populations Spanning the Past 2,000 Years
}

\author{
Christopher Aris $^{1,2 *}$ \\ ${ }^{1}$ Human Osteology Lab, Skeletal Biology Research Centre, School of Anthropology and \\ Conservation, University of Kent, Canterbury, UK
}

${ }^{2}$ Department of Applied Science, Wrexham Glyndwr University, Wrexham, UK

Keywords: enamel thickness, daily secretion rates

\begin{abstract}
This article represents an open repository of human enamel data collected/reconstructed from seven populations covering a 2,000 year time period in Britain via five temporally distinct periods. In total, data were collected from 285 permanent teeth, including maxillary and mandibular first molars, and maxillary canines and first incisors. Data were gathered through thin histological methods using standard procedures for sectioning human dental material. In regards to enamel growth, data is collected for daily secretion rates (DSRs) for the inner, mid, and outer areas of lateral and cuspal enamel. For enamel thickness average (AET) and relative (RET) enamel thickness, cuspal linear thickness (CT), and lateral linear thickness (LT) was collected. Alongside the data presented, this article also provides clear and transparent explanations for all the methods involved in its production, in order to ensure understanding of the rigorous protocol and consistency associated with the data provided. The novel data is also contextualised with a compilation of equivalent data published in past articles.
\end{abstract}

The microscopic study of modern human permanent enamel has commonly analysed both enamel thickness (e.g., Macho \& Berner, 1993; Reid and Dean, 2006; Suwa \& Kono, 2005; Smith et al., 2006a, 2006b; Aris et al., 2020b) and daily secretion rates (DSRs; e.g., Beynon et al., 1991a; Lacruz \& Bromage, 2006; Mahoney, 2008; Aris et al., 2020a; 2020b; Aris and Street, 2021). Both enamel thickness and DSRs have multiple component parts required for their reconstruction and analysis. For enamel thickness these include dentine area, enamel cap area, and enamel dentine junction length; and for DSRs include pre-averaged regional secretion rates collected across the enamel cap (e.g., Aris et al., 2020b). The complexity of these features of human enamel has allowed their subsequent analysis to be broad, but to date these have been inconsistent in coverage in terms of tooth type and enamel feature. For example, permanent molars have been widely analysed for their thickness (e.g., Schwartz, 2000; Suwa and Kono, 2005; Smith et al., 2006a, 2006b; Olejniczak, Smith, Feeney, Machiarelli, Mazurier, Bondioli, and Radovčić, 2008; Mahoney, 2010; Aris et al., 2020b) and cuspal DSRs (e.g., Beynon et al., 1991a; Lacruz and Bromage,
2006; Smith et al., 2007; Mahoney, 2008; Aris et al., 2020b). Conversely the study of permanent incisors and canines has seen very limited research for DSRs (FitzGerald, 1998; Reid, Benyon, and Ramirez Rozzi., 1998; Schwartz, Reid, and Dean, 2001; Aris et al., 2020a; Aris and Street, 2021) or for thickness outside of 3D analyses (e.g., Kono, Suwa, and Tanijiri, 2002; Kono and Suwa, 2008; Smith et al., 2012; Buti, LaCabec, Panetta, Tripodi, Salvadori, Hublin, and Benazzi, 2017). The study of lateral molar DSRs has been similarly limited (Beynon et al., 1991a; Lacruz and Bromage, 2006; Aris et al., 2020b).

In addition to the disproportionate use of microscopic enamel features across tooth types, outside of a select few examples, large data sets for perma-

*Correspondence to:

Christopher Aris

University of Kent

Wrexham Glyndwr University

Email: christopher.aris@glyndwr.ac.uk 
nent enamel features have not been presented or made openly accessible (e.g., Reid and Dean, 2006; Smith et al., 2006a). Furthermore, in the cases where developmental enamel variables are made available, outside of a few exceptions (e.g., Kono et al., 2002; Grine, 2004; Reid and Dean, 2006; Mahoney, 2010; Le Luyer et al., 2014; Buti et al., 2017), they are most frequently reported for single populations/samples. Moreover, such variables are also typically reported as averages for groups. Where individual-level enamel data has been reported, it has only concerned enamel thickness, and one single human sample (Kono et al., 2002; Skinner et al., 2015; Lockey et al., 2020). These single human samples were also generated as a comparative sample for equivalent hominin/hominoid data analysis, rather than in direct analysis of human enamel growth/morphological patterns. There is therefore a clear need for the further generation of developmental enamel variable data from multiple modern human populations, in order for intra-specific research of human dentition to continue - a topic that has seen a resurgence in recent years (e.g., Le Luyer, Rottier, and Bayle, 2014; Aris et al., 2020a, 2020b; Aris and Street 2021).

Since the pioneering of enamel thickness research involving human samples (e.g., Molnar and Gantt, 1977; Martin, 1983, 1985), a great deal of research has involved 2D sections of teeth. An area where enamel research has developed over time, and also been less restrictive, is within 3D analysis of anterior teeth (e.g., Feeney, Zermeno, Reid, Nakashima, Sano, Bahar, and Smith, 2010; Smith et al., 2012; Buti et al., 2017) and molars (e.g., KonoTakeuchi, Suwa, Kanazawa, and Tanijiri, 1997; Kono et al., 2002; Smith et al., 2006a; Kono and Suwa, 2008). These 3D-based studies have involved inter-species hominin analyses, as well as also developing the methodological approaches for intraspecific human enamel thickness analysis. Moreover, genetic analyses have also begun to emerge within the ongoing research of human enamel, which have made substantial strides to explaining inter-species enamel thickness differences within the human phylogeny (e.g., Horvath et al., 2014, Ungar and Hlusko, 2016). While possessing a clear utility, these lines of research do not directly or fully address all the issues discussed so far. They do however help show the importance of continued and nuanced research of human enamel. This therefore highlights the utility of providing more open access to relevant enamel thickness data.

Alongside the areas of inequality in research coverage and data availability regarding micro- scopic features of human enamel, there is a growing trend in intraspecific analyses investigating whether enamel growth and thickness has varied within the human species over relatively short periods of time. To date, these analyses have found significant variations in both enamel thickness and regional DSRs between geographically similar populations differing in context by as little as 400 years (Aris et al., 2020a; 2020b). This varies from older research in the field which frequently has either pooled dental samples for their growth and thickness data, or just used a single sample population, in order to create representative data sets for geographic regions or the entire human species (e.g., Beynon et al., 1991b; Lacruz and Bromage, 2006; Smith et al., 2007; Mahoney, 2008). While not all past research has pooled human populations (e.g., Grine, 2004; Reid and Dean, 2006), the prevalence towards doing so has meant that more recent research looking into whether the pooling of samples from different populations has been forced to create completely new histological sample collections to conduct their analyses. In these more recent analyses the use of comparative data sets from the pooled representative samples are limited in their utility (e.g., Aris et al., 2020b). In addition, while the production of new samples is useful to the field of dental anthropology, its destructive nature should be considered and pre-existing material used where possible and appropriate to help preserve dental remains wherever possible (Aris, 2020).

This article aims to address the above issues by providing a large and freely accessible data set for researchers to use in analysis of both enamel thickness and enamel growth, via DSR measures across multiple tooth types and for multiple (five) modern human populations, further presented alongside a guide for pre-existing equivalent data. The novel data sets will compromise individual-level data for individuals, as well as regional-level enamel measurements. Data of this type to date has not been reported or made available to this degree, with particular limitations existing regarding enamel growth data. The aim is that through this level of accessibility to this detailed a level of data, future research can more easily branch into the less well-covered features of enamel in current literature, and that further intraspecific research on modern humans can be conducted more easily. This will also represent the first data set regarding anterior tooth type enamel thickness accessible in this way. Finally, it is hoped that the open access publication of this data will help expand the analy- 
sis of enamel data gathered at the microscopic level clinical material (extracted within the last 20 years; to institutions unable to directly support histologi- Table 1). All archaeological samples came from cal and/or micro-CT methods.

\section{Material and Methods}

Dental sample

British excavations and modern-day samples compromised teeth extracted from England and Southern Scotland. Sex was estimated where possible from skeletal elements of the archaeological indiTo produce this repository, histological analysis viduals and known for a number of the modernwas conducted on 285 permanent teeth collected day samples. Details on known-sex/sex estimafrom seven populations across five temporally dis- tions are listed at the individual-level in the data tinct periods: Roman (70-400AD), Early Pre- sets, but a summary of the number of male and Medieval (500-600AD), Late Pre-Medieval (800- female individuals identified for each tooth type 1200AD), Medieval (1000-1600), and modern-day and population in provided in Table 2.

Table 1. Descriptive information of dental samples for each population and tooth type.

\begin{tabular}{|c|c|c|c|c|c|c|}
\hline \multirow[b]{2}{*}{ Population } & \multirow[b]{2}{*}{ Date } & \multirow[b]{2}{*}{ Location } & \multirow[b]{2}{*}{ Collection Name } & \multicolumn{3}{|c|}{ Number of teeth sampled } \\
\hline & & & & $\begin{array}{c}\text { Upper } \\
\text { incisors }\end{array}$ & $\begin{array}{c}\text { Upper } \\
\text { Canines }\end{array}$ & $\begin{array}{c}\text { First } \\
\text { Molars }\end{array}$ \\
\hline $\begin{array}{l}\text { All com- } \\
\text { bined }\end{array}$ & 70- 2000AD & $\begin{array}{l}\text { England and } \\
\text { Scotland }\end{array}$ & $\mathrm{N} / \mathrm{A}$ & 81 & 69 & 115 \\
\hline Roman & 70-400AD & $\begin{array}{l}\text { Cirencester, } \\
\text { Gloucester }\end{array}$ & $\begin{array}{l}\text { St James' Place/ } \\
\text { Bath Gate }\end{array}$ & 10 & 11 & 11 \\
\hline $\begin{array}{l}\text { Early Pre- } \\
\text { Medieval }\end{array}$ & 500-600AD & $\begin{array}{l}\text { Ramsgate, } \\
\text { Kent }\end{array}$ & Ozengell & 22 & 20 & 20 \\
\hline $\begin{array}{l}\text { Late Pre- } \\
\text { Medieval }\end{array}$ & 800-1200AD & $\begin{array}{l}\text { Newcastle-Upon- } \\
\text { Tyne, } \\
\text { Northumberland }\end{array}$ & Black Gate & 10 & 10 & 21 \\
\hline \multirow[t]{2}{*}{ Medieval } & 1100-1500AD & $\begin{array}{l}\text { Canterbury, } \\
\text { Kent }\end{array}$ & $\begin{array}{l}\text { St Gregory's } \\
\text { Priory }\end{array}$ & 19 & 8 & 43 \\
\hline & 1000-1600AD & $\begin{array}{l}\text { York, North } \\
\text { Yorkshire }\end{array}$ & Fishergate House & 8 & 8 & 5 \\
\hline $\begin{array}{l}\text { Modern- } \\
\text { day }\end{array}$ & $\begin{array}{l}\text { Extracted } \\
\text { within the } \\
\text { last } 20 \text { years }\end{array}$ & $\begin{array}{l}\text { Newcastle-Upon- } \\
\text { Tyne and Glas- } \\
\text { gow }\end{array}$ & UCL/Kent & 12 & 12 & 15 \\
\hline
\end{tabular}

Table 2. Descriptive information regarding the number of individuals across populations and tooth types with known-sex/sex estimations.

\begin{tabular}{|c|c|c|c|c|c|c|}
\hline \multirow[b]{2}{*}{ Population } & \multicolumn{3}{|c|}{ Number of male individuals } & \multicolumn{3}{|c|}{ Number of female individuals } \\
\hline & $\begin{array}{l}\text { Upper } \\
\text { incisors }\end{array}$ & $\begin{array}{l}\text { Upper } \\
\text { canines }\end{array}$ & $\begin{array}{c}\text { First } \\
\text { molars }\end{array}$ & $\begin{array}{l}\text { Upper } \\
\text { incisors }\end{array}$ & $\begin{array}{c}\text { Upper } \\
\text { canines }\end{array}$ & $\begin{array}{c}\text { First } \\
\text { molars }\end{array}$ \\
\hline \multicolumn{7}{|c|}{ Known sex } \\
\hline Modern-day & 5 & 9 & 4 & 7 & 3 & 5 \\
\hline \multicolumn{7}{|c|}{ Estimated sex } \\
\hline Early Pre-Medieval & 5 & 4 & 2 & 6 & 7 & 7 \\
\hline Late Pre-Medieval & 1 & 5 & 0 & 1 & 2 & 1 \\
\hline Medieval & 3 & 4 & 1 & 3 & 3 & 0 \\
\hline Roman & 2 & 5 & 6 & 3 & 4 & 1 \\
\hline
\end{tabular}


Unworn teeth were selected where possible. storage and dissemination of special data relating When worn, only teeth with approximately $80 \%$ of to an individual's personal identity) the only infortheir crown height remaining were selected based mation available was the biological sex and town/ on criteria outlined by Guatelli-Steinberg and col- city location from which the individual had the leagues (2005), and when wear was present no data tooth sampled extracted.

relating to the cuspal region of the enamel cap was collected (Figure 1). One tooth was taken from each individual during the sampling process, following the guidelines for destructive sampling of human remains guideline outlined by Mays and colleagues (2013) and on request from the institutions which curated the dental material utilised (see acknowledgements). Left teeth were utilised wherever possible, with the right tooth only being used in instances where the left was missing, poorly preserved, or heavily damaged (data files note whether left or right were analysed). Selection preference was also given to individuals presenting an antimere to the tooth being selected for sectioning.

\section{Roman samples}

The Roman samples were from two similarly located sites in Cirencester: St James' Place and Bath Gate cemeteries (Figure 2). Both sites dated between 70-400AD (see Table 1), presented archaeological material consistent with Roman-British populations, and are thought to have been small urban populations with access to marine resources from the River Severn (McWhirr et al., 1982).

\section{Early Pre-Medieval samples}

The Early Pre-Medieval samples came from a site in Thanet, Ozengell Grange (see Figure 2), dated to

Ancestry was unknown for all individuals 500-600AD (see Table 1). The population is thought across all populations from which samples were to have been small and coastal, with regular access taken. In the case of the archaeological collections to marine resources from the North Sea and/or the this was due to individual records not existing for English Channel (Millard et at al., 1969). The Preany of the individuals of any of the populations Medieval period in Thanet is associated with newstudied. For the modern-day individuals, due to ly developing urban areas following Roman occuGDPR data laws (specifically those limiting the pation (McKinley et al., 2015).
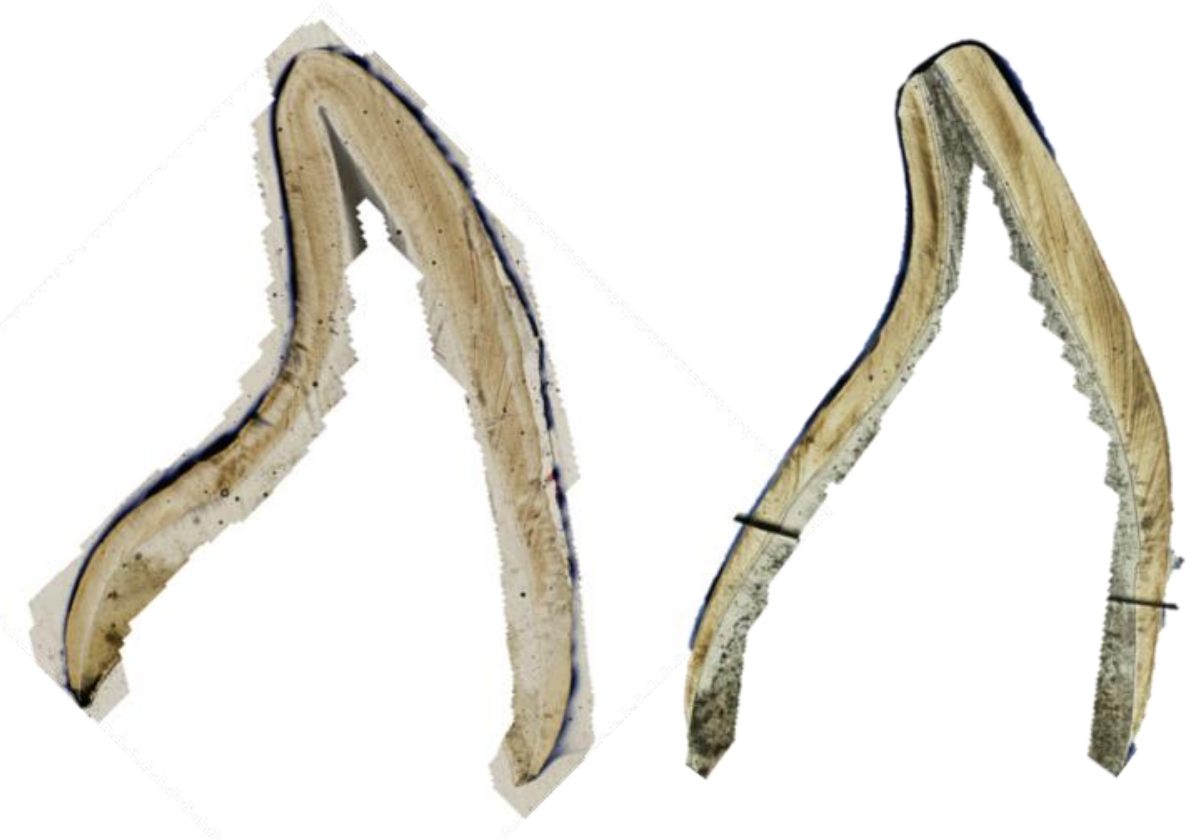

Figure 1. Cross sections displaying examples of worn and unworn teeth analysed. The left cross section, a Medieval upper first incisor, displays no occlusal wear. The right cross section, a Roman upper first incisor, displays occlusal wear and thus no data requiring the cuspal region was collected from it. 


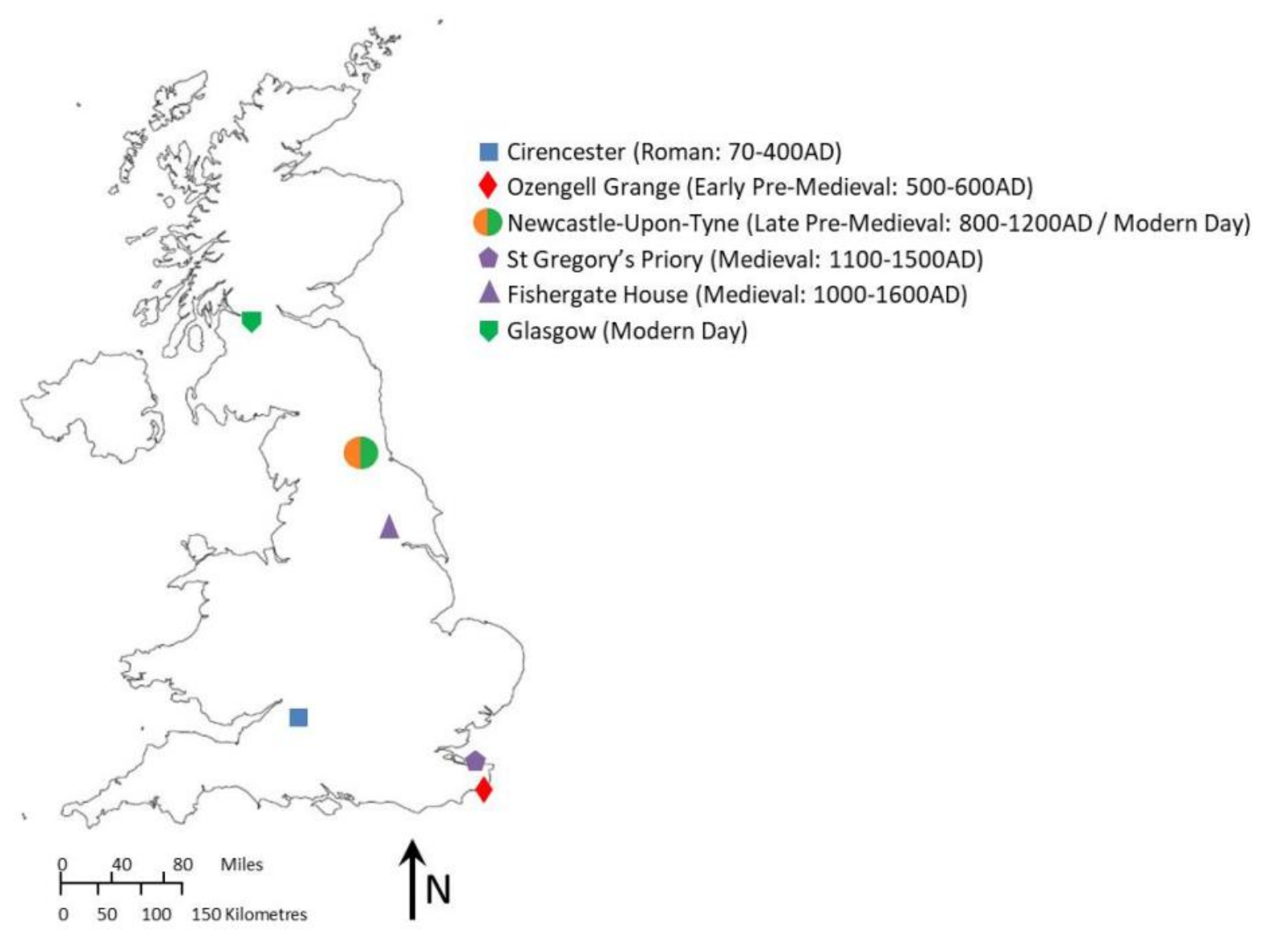

Figure 2. Map of the United-Kingdom and Northern Ireland displaying the geographic location where the archaeological samples were excavated/modern-day samples were extracted. Shapes denote the samples geographic origin, colour the time period they associated with (multi coloured shapes thereby meaning individuals from more than one time period originated from the same location): Roman = Blue, Early Pre-Medieval $=$ Red, Late Pre-Medieval $=$ Orange, Medieval $=$ Purple, Modern-day $=$ Green . Similar guides to these populations' context can be found in articles by Aris and colleagues (2020a, 2020b).

Late Pre-Medieval samples

The Late Pre-Medieval sample came from the Black Gate Cemetery site in Newcastle-Upon-Tyne (see Figure 2), dated to $800-1200 \mathrm{AD}$ (see Table 1). This was a large urban population with access to marine resources through proximity to the River Tyne (Swales, 2012).

\section{Medieval samples}

The Medieval samples come from two sites: St ject ID: 203541).

Gregory's Priory, Canterbury, and Fishergate House, York (see Figure 2). The sites were dated between 1100-1500AD (Hicks and Hicks, 2001) and 1000-1600AD (Holst, 2001) respectively (see Table 1). Both are documented to have been large urban populations (Hicks and Hicks, 2001; Holst, 2001).
Modern-day samples

The modern-day samples came from the UCL/ Kent collection, a repository of teeth collected from dental surgeries in northern England (NewcastleUpon-Tyne) and southern Scotland (Glasgow) (see Figure 2). Ethical approval for histology research on this collection of teeth was obtained from the United Kingdom National Health Service research ethics committee (REC reference: 16/SC/0166; pro-

\section{Sample Preparation}

Before any tooth was sectioned as a part of producing the data set, resin casts were produced for each incisor, canine and molar using standard methods (Aris, 2020). Producing casts in this way allows for 
the reproduction of the surface morphology of dental crown, thus allowing for future researchers to analyse features not within the data such, such as crown morphology, microwear, and enamel surface features including perikymata and linear enamel hypoplasia.

Thin sections were produced using standard histological procedures (e.g., Mahoney, 2008; Aris, 2020). All teeth were first embedded in an epoxy resin and hardener mixture $\left(\right.$ Buehler $\left.{ }^{\circledR}\right)$ in order to minimise the possibility of teeth fracturing during the sectioning process. Embedded samples were then cut at low speeds using a diamond-edged wafering blade (Buehler ${ }^{\circledR}$ IsoMet 1000 Precision Cutter) through the apex of crown cusps at a longitudinal angle. Samples were then mounted on glass microscope slides and subsequently lapped using grinding pads (Buehler ${ }^{\circledR}$ ) until around $120 \mu \mathrm{m}$ thick. Ground samples were then polished using $0.3 \mu \mathrm{m}$ aluminium oxide powder to remove any evidence of lapping. Polished samples were then placed within an ultrasonic bath for a two-minute period in order to remove any micro-debris before being dehydrated using $90 \%$ and $100 \%$ ethanolbased solutions (Fisher scientific ${ }^{\circledR}$ ). Dehydrated sections were finally cleared using Histoclear ${ }^{\circledR}$ and mounted with a glass cover slip using a mounting medium $\left(\mathrm{DPX}^{\circledR}\right)$. All sections were examined using polarised light microscopy (Olympus BX53 Upright Microscope). Analysis and image capture was conducted using micro imaging software (cellSens).

Due to the requirements for cuts to be made precisely through the cusp and dentine horn apex in order for enamel growth and thickness data collected to be reliable (Aris et al., 2020b), lines were marked on the tooth to help guide the initial cutting of the teeth for each tooth type (Figure 3). Whether this method was successful was assessed by observing the shape of the dentine horn of each cross section - a sharp point (with a V-shaped appearance; Smith et al., 2006a) at the apex denotes and precise cut; a curved/rounded apex a misaligned oblique cut (Reid and Guatelli-Steinberg, 2017). Where oblique cuts were noted the associated sections were not used for data collection (Figure 4).

\section{Measurements Taken}

Daily secretion rates

Daily secretion rates were reconstructed using standard methods for the inner, mid, and outer regions of the lateral and cuspal enamel areas of each tooth (e.g., Beynon et al., 1991a; Mahoney, 2008; Schwartz et al., 2001). Regions were determined by dividing the length of the associated

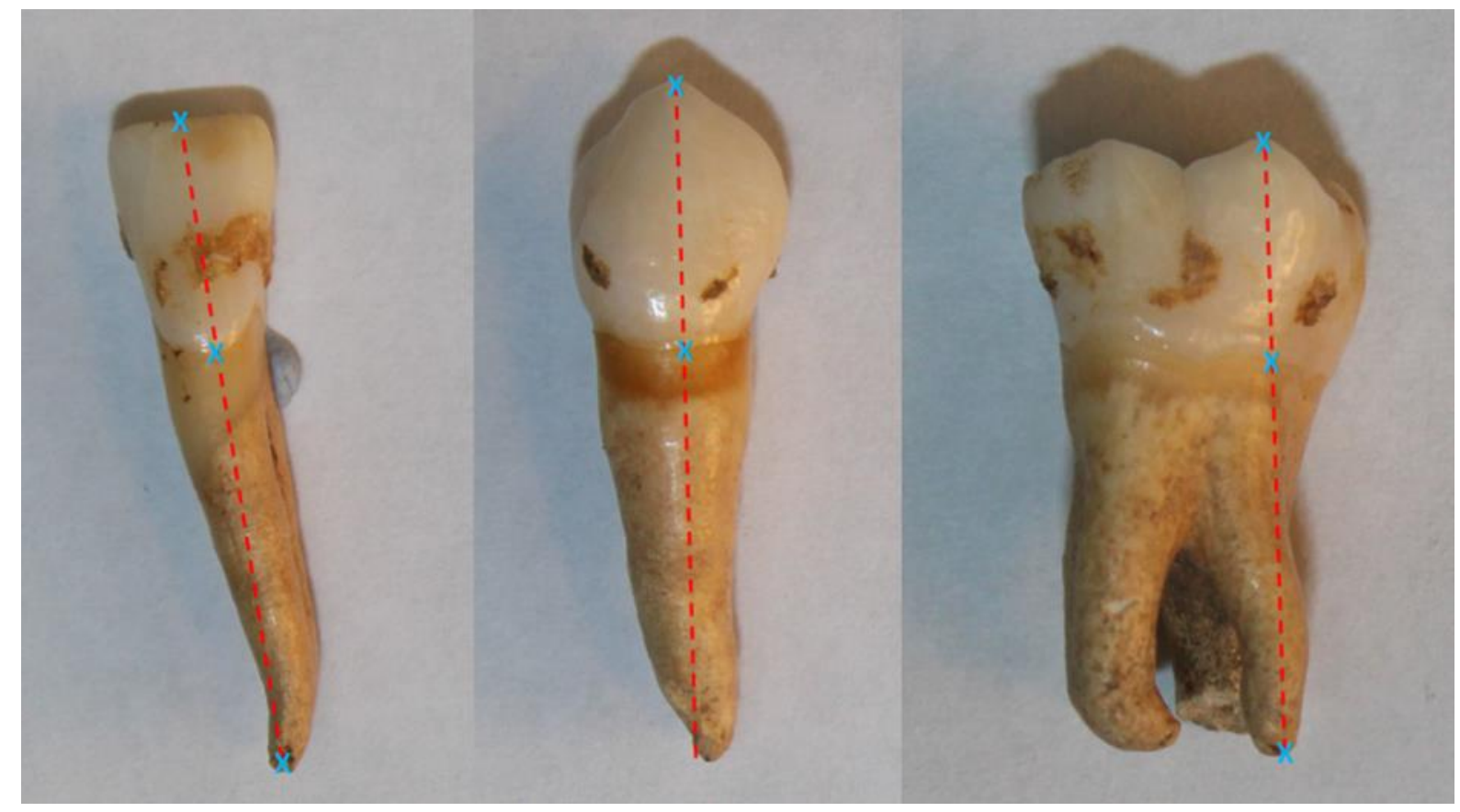

Figure 3. Diagram of how marks were made on upper first incisors, upper canines, and first molars (left to right respectively) before cutting to create a line through the cusp apex and dentine horn. The dashed red line displays the line created by the marks made at the blue crosses. Note the lack of blue cross on the unaligned root apex of the upper canine. The teeth displayed all came from the Fishergate House Medieval collection 


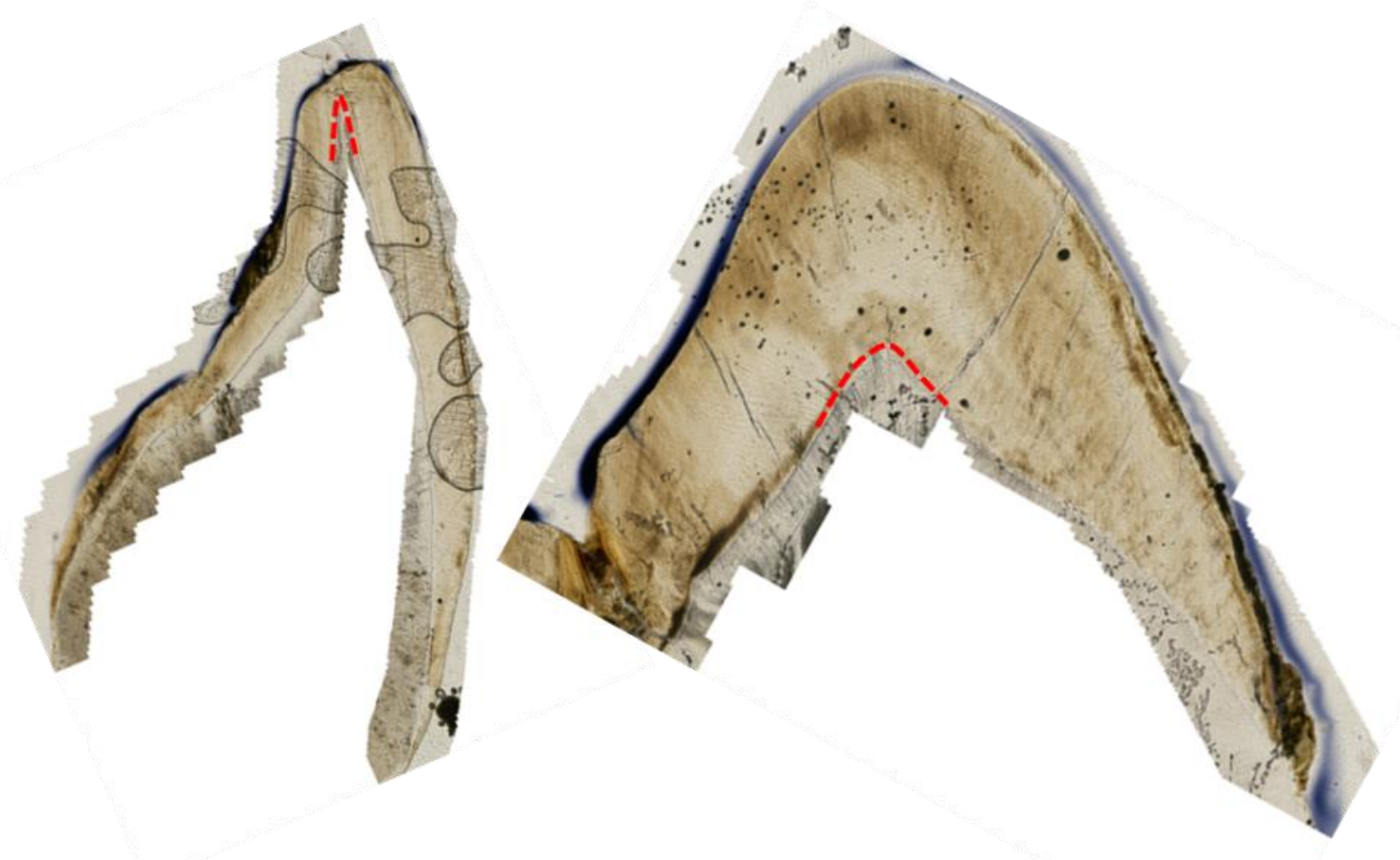

Figure 4. Cross sections displaying aligned and misaligned cuts, both observed through the shape of the dentine horn (highlighted with dashed red lines). The left cross section, a Medieval upper first incisor, displays an aligned cut with sharp pointed, V-shaped, dentine horn apex. The right cross section, a Roman first molar, displays a misaligned cut with a rounded dentine horn.

enamel area into three equal parts along the length Enamel thickness

of enamel prisms. Cuspal enamel regions were de- For each tooth, four 2D measures of enamel thicktermined within the appositional enamel of each ness were calculated: cuspal thickness (CT), lateral tooth, and DSRs were taken from the mesial cusps thickness (LT), relative enamel thickness (RET), of molar teeth. Lateral enamel regions were deter- and average enamel thickness (AET). Each was mined within the area of imbricational enamel measured and calculated using a composite image equidistant between the dentine horn and the den- produced by stitching together 20x magnified imtal cervix. Lateral DSRs were taken from the buccal ages using cellSens digital software.

-mesial cusps of molar teeth, and from the labial enamel of canine and incisor teeth.

For each region an initial measurement was made for the length of five adjacent cross striations following the long axis of an appropriate enamel prism. This measurement was then divided by five to give a mean daily rate of secretion $(\mu \mathrm{m} /$ day). This process was repeated five times to give a grand mean and standard deviation for each region of each tooth. Cross striation measurements were all taken at between 20x and 40x magnification. Figure 5 illustrates how cuspal and lateral regions were split and how cross striations were counted along enamel prisms.

RET is a dimensionless index and free-scale derivative of the average enamel thickness (AET) which encompasses the entire 2D surface area of an enamel cross section. AET $(\mathrm{mm})$ is calculated by dividing the surface area by the length of the EDJ (enamel dentine junction) (Martin, 1983). RET is then calculated by dividing the associated AET by the square root of the dentine surface area of the surrounding EDJ and bi-cervical diameter (e.g., Smith et al., 2006a; Olenjniczak et al., 2008; Figure 6).

Cuspal thickness was taken from the buccalmesial cups of the molars and primary cusp of the incisors and canines. Lateral thickness was also 


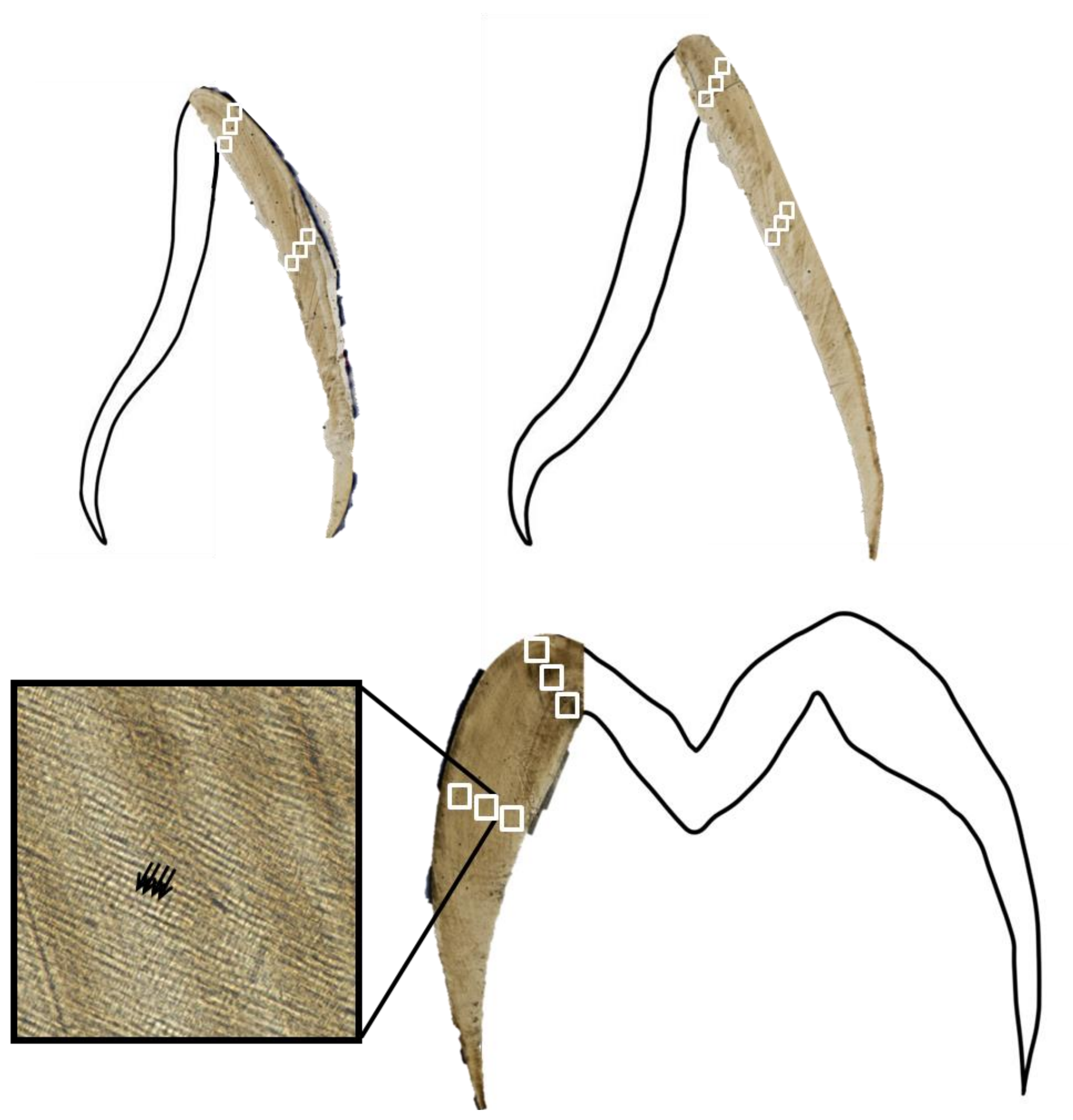

Figure 5. Diagrams of incisor (top left), canine (top right), and molar (bottom) cross sections with inner, mid, and outer regions for cuspal and lateral enamel regions isolated for DSR analysis. White squares show these enamel regions. The black square shows a 40x magnified superimposition of the mid lateral molar enamel. Black arrows indicate individual cross striations. 

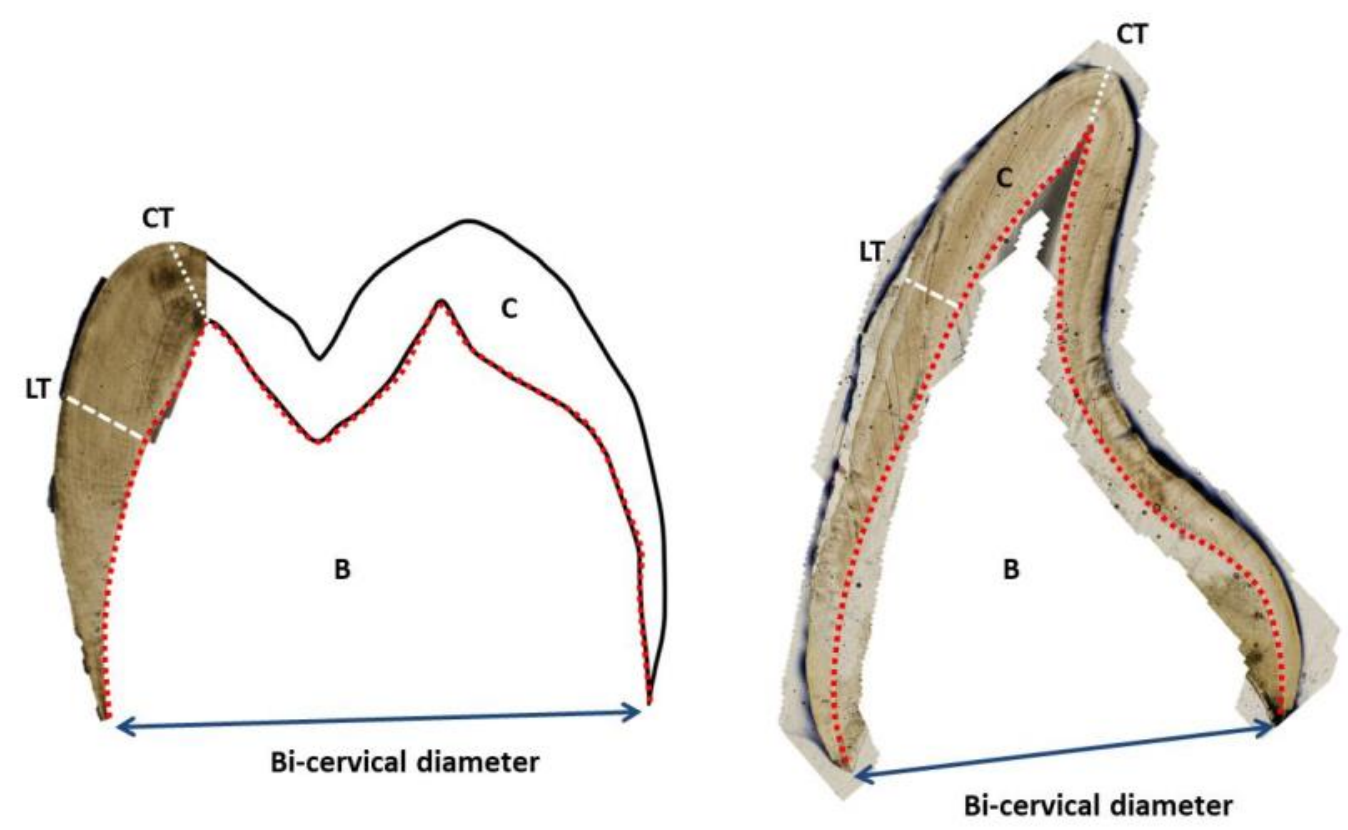

Figure 6. Cross-sectional images and reconstructions of 2D enamel thickness measures taken for molars (left) and canines and incisors (right). C. the enamel cap area and $\mathbf{B}$. the dentine encompassed by the enamel and bi-cervical diameter (double-headed arrow). The area of $\mathbf{C}$. was divided by the length of the EDJ (marked by dotted red line) to give the average enamel thickness (AET) in mm. The AET is divided by the square root of the area of $\mathbf{B}$ and multiplied by 100 to give the relative enamel thickness (RET) (e.g. Martin, 1983), which is a dimensionless index. The dotted white lines (CT) illustrate the cuspal enamel thickness measurements (e.g. Beynon and Wood, 1986). The dashed white lines (LT) illustrate lateral enamel thickness measurements (e.g. Grine and Martin, 1988). Similar guides to taking these measures can also be found in an article by Aris and colleagues (2020b).

taken from the mesial cusps of the molars, and piling this data it is easier to identify where the from the labial region of incisor and canine enamel. novel data presented here fills temporal and/or Cuspal thickness (mm) was calculated by measuring the distance between the apex of the dentine horn and the cusp tip. Lateral thickness $(\mathrm{mm})$ was calculated by measuring the maximum length between the EDJ and the enamel surface along a line perpendicular to the EDJ. The location of this line determined within the area of the tooth between the dental cervix and the first Retzius line to form in contact with the outer enamel surface (see dotted lines of Figure 1). These two linear measurements have been presented in past studies under different abbreviations (Beynon and Wood, 1986; Grine, 2005; Hlusko et al., 2004; Mahoney, 2010; Schwartz, 2000a, 2000b).

Pre-existing data

Equivalent data to that which is provided in this article, regarding enamel secretion rates and thickness, has been routinely published in studies regarding human enamel. A large number of those articles were compiled with details as to the enamel variables analysed and context information of relevant human samples, in order to contextualise the novel data generated for this project. By comgeographical gaps in existing data, and thus where gaps also persist. Where the same data has been utilised in multiple published works only one is detailed; preference was given to the original source where possible (Table 3 ).

Note: Articles using similar data which have been published to date but are not included are those which utilised the data sets provided in this article (Aris et al., 2020a, 2020b; Aris and Street, 2021).

\section{Conclusions}

Data utility

The combined data sets presented here represent the largest data repository of its kind in relation to developmental variables of human enamel in both archaeological and modern contexts. Moreover, it holds particular value in being the only such data set available which lists individual-level data for enamel growth and thickness for multiple tooth types and multiple different populations. This will allow for future research to have wider accessibility to comparative data for both intra- and interspecies and population analyses of permanent enamel involving human samples. Moreover, it is 
Table 3. Existing published data for enamel DSRs and relevant thickness measures detailed with temporal and geographic contexts, tooth type information, and level at which data is available.

\begin{tabular}{|c|c|c|c|c|c|c|c|}
\hline \multirow[t]{2}{*}{ Source } & \multirow[t]{2}{*}{ Location } & \multirow[t]{2}{*}{ Time Period } & \multirow[t]{2}{*}{ Tooth Types } & \multirow[t]{2}{*}{$\mathrm{N}$} & \multicolumn{2}{|c|}{ Data collected } & \multirow{2}{*}{$\begin{array}{l}\text { Data level } \\
\text { presented at }\end{array}$} \\
\hline & & & & & Cuspal DSRs & Lateral DSRs & \\
\hline \multicolumn{8}{|c|}{ DSR data } \\
\hline $\begin{array}{l}\text { Beynon et al., } \\
\text { 1991b }\end{array}$ & Unknown & Unknown & Molars & $11-15$ & $\mathrm{X}$ & $x$ & Species \\
\hline $\begin{array}{l}\text { Lacruz and } \\
\text { Bromage, } \\
2006\end{array}$ & Unknown & Unknown & Molars & 10 & 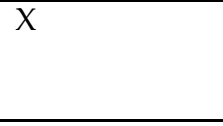 & 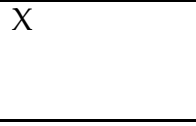 & Species \\
\hline $\begin{array}{l}\text { Smith et al., } \\
2007\end{array}$ & Various & Various & First molars & 21 & $x$ & & Species \\
\hline $\begin{array}{l}\text { Smith et al., } \\
2009\end{array}$ & Germany & Modern-day & Third molars & 7 & $\mathrm{X}$ & & Species \\
\hline $\begin{array}{l}\text { Mahoney, } \\
2008\end{array}$ & $\begin{array}{l}\text { England and Scot- } \\
\text { land }\end{array}$ & Bronze-Age & First molars & 13 & $\bar{X}$ & & Population \\
\hline $\begin{array}{l}\text { Schwartz et } \\
\text { al., } 2001\end{array}$ & $\begin{array}{l}\text { England and } \\
\text { South Africa }\end{array}$ & Modern-day & Canines & 28 & $x$ & $x$ & Sex \\
\hline \multicolumn{8}{|c|}{ Thickness data } \\
\hline Source & Location & Time Period & Tooth Types & $\mathrm{N}$ & RET & LT & $\begin{array}{l}\text { Data level } \\
\text { presented at }\end{array}$ \\
\hline $\begin{array}{l}\text { Smith et al., } \\
\text { 2006a and b* }\end{array}$ & Various & $\begin{array}{l}\text { Middle Stone } \\
\text { Age and } \\
\text { Modern-day }\end{array}$ & Molars & $1-55$ & $\mathrm{X}$ & & Population \\
\hline $\begin{array}{l}\text { Olejniczak et } \\
\text { al., 2008* }\end{array}$ & $\begin{array}{l}\text { Various and un- } \\
\text { known }\end{array}$ & $\begin{array}{l}\text { Various and } \\
\text { unknown }\end{array}$ & First molars & $1-6$ & $\bar{X}$ & & Species \\
\hline Lockey, 2020 & Unknown & Unknown & Molars & $9-10$ & $x$ & & Individual \\
\hline Martin, 1983 & Unknown & Unknown & Molars & 13 & $x$ & & Species \\
\hline $\begin{array}{l}\text { Skinner et al., } \\
2015\end{array}$ & Various & Unknown & Molars & $8-15$ & 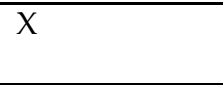 & & Individual \\
\hline $\begin{array}{l}\text { Smith et al., } \\
2009\end{array}$ & Germany & Modern-day & Third molars & 8 & $\mathrm{X}$ & & Species \\
\hline $\begin{array}{l}\text { Smith et al., } \\
2008\end{array}$ & Various & Various & Various & $12-58$ & $x$ & & Species \\
\hline $\begin{array}{l}\text { Sorenti et al., } \\
2019\end{array}$ & Madrid, Spain & 20 th Century & Molars & $20-31$ & $\bar{X}$ & & Sex \\
\hline Kono, 2004* & Asia & Various & Molars & $40-41$ & $x$ & $x$ & Population \\
\hline Grine, 1991 & Unknown & Unknown & First molars & 10 & $x$ & $x$ & Species \\
\hline Grine, 2004 & Various & Modern-day & $\begin{array}{l}\text { Second mo- } \\
\text { lars }\end{array}$ & $1-23$ & $\bar{X}$ & $\bar{x}$ & Population \\
\hline $\begin{array}{l}\text { Reid and } \\
\text { Dean, } 2006\end{array}$ & Various & Various & Various & $15-37$ & $\bar{x}$ & & Population \\
\hline $\begin{array}{l}\text { Gantt and } \\
\text { Rafter, } 1998\end{array}$ & Unknown & Unknown & Molars & $3-23$ & $x$ & $x$ & Species \\
\hline $\begin{array}{l}\text { Mahoney, } \\
2010\end{array}$ & $\begin{array}{l}\text { England and Scot- } \\
\text { land }\end{array}$ & Various & Molars & 69 & $x$ & $x$ & Population \\
\hline $\begin{array}{l}\text { Suwa and } \\
\text { Kono, 2005* }\end{array}$ & Ohio, USA & 800-1100AD & First molars & $31-37$ & $\mathrm{X}$ & $x$ & Population \\
\hline $\begin{array}{l}\text { Kono et al., } \\
2002^{*}\end{array}$ & Asia & Unknown & First molars & 5 & $\mathrm{X}$ & $x$ & Individual \\
\hline $\begin{array}{l}\text { Macho and } \\
\text { Berner, } 1993\end{array}$ & $\begin{array}{l}\text { Zwentendorf, } \\
\text { Austria }\end{array}$ & 1100AD & First molars & 21 & & $x$ & Population \\
\hline $\begin{array}{l}\text { Saunders et } \\
\text { al., } 2007\end{array}$ & Belleville, Canada & 1821-1874AD & $\begin{array}{l}\text { Canines and } \\
\text { premolars }\end{array}$ & 72 & $x$ & & Sex \\
\hline $\begin{array}{l}\text { Feeney et al., } \\
2010^{*}\end{array}$ & Indonesia & Modern-day & Canines & $7-21$ & $\bar{X}$ & & Population \\
\hline $\begin{array}{l}\text { Buti et al., } \\
2017^{*}\end{array}$ & Various & $\begin{array}{l}\text { Medieval } \\
\text { and Clinical }\end{array}$ & Canines & $1-13$ & $\mathrm{x}$ & & Population \\
\hline
\end{tabular}

*Some or all data generated within a 3D context 
hoped that the compilation of similar data available in past research publications here will assist in researchers locating suitable comparative data regarding enamel growth and thickness data in addition to that provided here.

For specific examples of the data's utility, all articles which have utilised any data presented here compromise the work of Aris (2020), Aris and colleagues (2020a, 2020b), and Aris and Street (2021). Throughout these articles, all content here including enamel DSRs, enamel thickness, and methodological approaches, are used in specific research projects.

Data ethics and acknowledgements

Data of the kind presented here is collected via destructive methods, which has a permanent impact on the collections analysed, and thereby their curating institutions. As a result, while this data is publicly available for use in future research, it is strongly recommended that such research acknowledge both the generosity and ethical stringency of the curators acknowledged in this article. Moreover, further care must be taken when utilising the modern-day data from the UCL/Kent collection. Not only should the University of Kent be acknowledged, but it should be detailed that the ethical approval for histological research on this collection of teeth was obtained from the United Kingdom National Health Service research ethics committee. Furthermore, the REC reference: 16/ SC/0166; project ID: 203541, should also be noted (as it has been here in section 2.1.5).

\section{Acknowledgements}

Thanks go to the Corinium Museum, Trust for Thanet Archaeology, and the Universities of Durham, Kent, and Sheffield for granting permission to sample the teeth sectioned as a part of developing this repository. Thanks also go to the two anonymous reviewers and editor for their positive feedback and comments which helped greatly improve this article.

\section{REFERENCES}

Aris, C. (2020). The histological paradox: Methodology and efficacy of dental sectioning. Papers from the Institute of Archaeology, 29(1), 1-16.

Aris, C., Mahoney, P., \& Deter, C. (2020a). Enamel thickness and growth rates in modern human permanent first molars over a 2000 year period in Britain. American Journal of Physical Anthropology, 173(1), 141-157.

Aris, C., Mahoney, P., O'Hara, M. C., \& Deter, C. (2020b). Enamel growth rates of anterior teeth in males and females from modern and ancient British populations. American Journal of Physical Anthropology, 173(2), 236-249.

Aris, C., \& Street, E. (2021). Growth rates of accessory human enamel: a histological case study of a modern-day incisor from Northern England. Dental Anthropology Journal, 34(1), 3-12.

Beynon, A. D., Dean, M. C., \& Reid, D. J. (1991a). Histological study on the chronology of the developing dentition in gorilla and orangutan. American Journal of Physical Anthropolo$g y, 86(2), 189-203$.

Beynon, A. D., Dean, M. C., \& Reid, D. J. (1991b). On thick and thin enamel in hominoids. American Journal of Physical Anthropolo$g y, 86(2), 295-309$.

Beynon, A. D., \& Wood, B. A. (1986). Variations in enamel thickness and structure in East African hominids. American Journal of Physical Anthropology, 70(2), 177-193.

Buti, L., Le Cabec, A., Panetta, D., Tripodi, M., Salvadori, P. A., Hublin, J. J., \& Benazzi, S. (2017). 3D enamel thickness in Neandertal and modern human permanent canines. Journal of $\mathrm{Hu}$ man Evolution, 113, 162-172.

Feeney, R. N., Zermeno, J. P., Reid, D. J., Nakashima, S., Sano, H., Bahar, A., \& Smith, T. M. (2010). Enamel thickness in Asian human canines and premolars. Anthropological Science, 118(3), 191-198.

FitzGerald, C. M. (1998). Do enamel microstructures have regular time dependency? Conclusions from the literature and a large-scale study. Journal of Human Evolution, 35(4-5), 371386.

Gantt, D. G., \& Rafter, J. A. (1998). Evolutionary and functional significance of hominoid tooth enamel. Connective Tissue Research, 39(1-3), 195206.

Grine, F. E. (1991). Computed tomography and the measurement of enamel thickness in extant hominoids: implications for its palaeontological application. Palaeontologica Africana, 28(1), 61-69.

Grine, F. E. (2004). Geographic variation in human tooth enamel thickness does not support Neandertal involvement in the ancestry of modern Europeans. South African Journal of Science, 100 (7), 389-394.

Grine, F. E. (2005). Enamel thickness of deciduous and permanent molars in modern Homo sapiens. American Journal of Physical Anthropology, 126(1), 14-31.

Grine, F.E. and Martin, L.B. (1988). Enamel thickness and development in Australopithecus and 
Paranthropus. In: Grine, F.E. (Ed.), Evolutionary History of the "Robust" Australopithecines (pp. 342). New York, Aldine de Gruyter.

Guatelli-Steinberg, D., Reid, D. J., Bishop, T. A., \& Larsen, C. S. (2005). Anterior tooth growth periods in Neandertals were comparable to those of modern humans. Proceedings of the National Academy of Sciences, 102(40), 14197-14202.

Hicks, M., \& Hicks, A. (2001). St Gregory's Priory, Northgate, Canterbury: Excavations 19881991 (Vol. 2). Canterbury Archaeological Trust Limited.

Hlusko, L. J., Suwa, G., Kono, R. T., \& Mahaney, M. C. (2004). Genetics and the evolution of primate enamel thickness: a baboon model. American Journal of Physical Anthropology, 124(3), 223-233.

Horvath, J. E., Ramachandran, G. L., Fedrigo, O., Nielsen, W. J., Babbitt, C. C., Clair, E. M. S., \& Wall, C. E. (2014). Genetic comparisons yield insight into the evolution of enamel thickness during human evolution. Journal of Human Evolution, 73, 75-87.

Kono, R. T. (2004). Molar enamel thickness and distribution patterns in extant great apes and humans: new insights based on a 3dimensional whole crown perspective. Anthropological Science, 112(2), 121-146.

Kono, R. T., \& Suwa, G. (2008). Enamel distribution patterns of extant human and hominoid molars: occlusal versus lateral enamel thickness. Bulletin of the National Science Museum, Tokyo, Series D, 34, 1-9.

Kono, R. T., Suwa, G., \& Tanijiri, T. (2002). A threedimensional analysis of enamel distribution patterns in human permanent first molars. Archives of Oral Biology, 47(12), 867-875.

Kono-Takeuchi, R., Suwa, G., Kanazawa, E., \& Tanijiri, T. (1997). A new method of evaluating enamel thickness based on a three-dimensional measuring system. Anthropological Science, 105 (4), 217-229.

Lacruz, R. S., \& Bromage, T. G. (2006). Appositional enamel growth in molars of South African fossil hominids. Journal of Anatomy, 209(1), 1320.

Le Luyer, M., Rottier, S., \& Bayle, P. (2014). Brief communication: Comparative patterns of enamel thickness topography and oblique molar wear in two early Neolithic and medieval population samples. American Journal of Physical Anthropology, 155(1), 162-172.

Lockey, A. L, Alemseged Z, Hublin J. J, Skinner M. M. (2020). Maxillary molar enamel thickness of
Plio-Pleistocene hominins. Journal of Human Evolution, 142(1), 102731.

Macho, G. A., \& Berner, M. E. (1993). Enamel thickness of human maxillary molars reconsidered. American Journal of Physical Anthropology, 92(2), 189-200.

Mahoney, P. (2008). Intraspecific variation in M1 enamel development in modern humans: implications for human evolution. Journal of $\mathrm{Hu}$ man Evolution, 55(1), 131-147.

Mahoney, P. (2010). Two-dimensional patterns of human enamel thickness on deciduous ( $\mathrm{dm} 1$, $\mathrm{dm} 2$ ) and permanent first (M1) mandibular molars. Archives of Oral Biology, 55(2), 115-126.

Martin, L. B. (1983). The Relationships of the Later Miocene Hominoidea (Doctoral dissertation, University of London).

Martin, L.B., (1985). Significance of enamel thickness in hominoid evolution. Nature, 314, 260263.

Mays, S., Elders, J., Humphrey, L., White, W., \& Marshall, P. (2013). Science and the dead: a guideline for the destructive sampling of archaeological human remains for scientific analysis. English Heritage Publishing with the Advisory Panel on the Archaeology of Burials in England.

McKinley, J. I., Leivers, M., Schuster, J., \& Marshall, P. (2015). Cliffs End Farm Isle of Thanet, Kent: A mortuary and ritual site of the Bronze Age, Iron Age and Anglo-Saxon period with evidence for long -distance maritime mobility. Wessex Archaeology.

McWhirr, A., Viner, L., \& Wells, C. (1982). Romano -British Cemeteries at Cirencester: Cirencester Excavations II. Cirencester Excavation Committee. Cirencester.

Millard, L., Jarman, S., \& Hawkes, S. C. (1969). Anglo-Saxon Burials Near the Lord of the Manor, Ramsgate: New Light on the Site of Ozengell? Headley Bros.

Molnar, S., \& Gantt, D. G. (1977). Functional implications of primate enamel thickness. American Journal of Physical Anthropology, 46(3), 447-454.

Olejniczak, A. J., Smith, T. M., Feeney, R. N., Macchiarelli, R., Mazurier, A., Bondioli, L., \& Radovčić, J. (2008). Dental tissue proportions and enamel thickness in Neandertal and modern human molars. Journal of Human Evolution, 55 (1), 12-23.

Reid, D. J., Beynon, A. D., \& Ramirez Rozzi, F. V. (1998). Histological reconstruction of dental development in four individuals from a medieval site in Picardie, France. Journal of Human Evolution, 35(4-5), 463-477. 
Reid, D. J., \& Dean, M. C. (2006). Variation in modern human enamel formation times. Journal of Human Evolution, 50(3), 329-346.

Reid, D. J., \& Guatelli-Steinberg, D. (2017). Updating histological data on crown initiation and crown completion ages in southern Africans. American Journal of Physical Anthropolo$g y, 162(4), 817-829$.

Saunders, S. R., Chan, A. H., Kahlon, B., Kluge, H. F., \& FitzGerald, C. M. (2007). Sexual dimorphism of the dental tissues in human permanent mandibular canines and third premolars. American Journal of Physical Anthropolo$g y, 133(1), 735-740$.

Schwartz, G. T. (2000a). Enamel thickness and the helicoidal wear plane in modern human mandibular molars. Archives of Oral Biology, 45(5), 401-409.

Schwartz, G. T. (2000b). Taxonomic and functional aspects of the patterning of enamel thickness distribution in extant large-bodied hominoids. American Journal of Physical Anthropolo$g y, 111(2), 221-244$.

Schwartz, G. T., Reid, D. J., \& Dean, C. (2001). Developmental aspects of sexual dimorphism in hominoid canines. International Journal of Primatology, 22(5), 837-860.

Skinner M. M, Alemseged Z, Gaunitz C, Hublin J. J. (2015). Enamel thickness trends in PlioPleistocene hominin mandibular molars. Journal of Human Evolution, 8(1), 35-45.

Smith, T. M., Harvati, K., Olejniczak, A. J., Reid, D. J., Hublin, J. J., \& Panagopoulou, E. (2009).

Brief communication: dental development and enamel thickness in the Lakonis Neanderthal molar. American Journal of Physical Anthropolo$g y, 138(1), 112-118$.

Smith, T. M., Olejniczak, A. J., Reh, S., Reid, D. J., \& Hublin, J. J. (2008). Brief communication:

enamel thickness trends in the dental arcade of humans and chimpanzees. American Journal of Physical Anthropology, 136(2), 237-241.

Smith, T. M., Olejniczak, A. J., Reid, D. J., Ferrell, R. J., \& Hublin, J. J. (2006a). Modern human molar enamel thickness and enamel-dentine junction shape. Archives of Oral Biology, 51(11), 974-995

Smith, T. M., Olejniczak, A. J., Tafforeau, P., Reid, D. J., Grine, F. E., \& Hublin, J. J. (2006b). Molar crown thickness, volume, and development in South African Middle Stone Age humans. South African Journal of Science, 102(11), 513-517.

Smith, T. M., Olejniczak, A. J., Zermeno, J. P., Tafforeau, P., Skinner, M. M., Hoffmann, A., \&
Hublin, J. J. (2012). Variation in enamel thickness within the genus Homo. Journal of Human Evolution, 62(3), 395-411.

Smith, T. M., Reid, D. J., Dean, M. C., Olejniczak, A. J., \& Martin, L. B. (2007). New perspectives on chimpanzee and human molar crown development. In S. E. Bailey \& J. J. Hublin (Eds.), Dental perspectives on human evolution: state of the art research in dental paleoanthropology (pp.177-192). Berlin: Springer.

Sorenti, M., Martinón-Torres, M., Martín-Francés, L., \& Perea-Pérez, B. (2019). Sexual dimorphism of dental tissues in modern human mandibular molars. American Journal of Physical Anthropology, 169(2), 332-340.

Suwa, G., \& Kono, R. T. (2005). A micro-CT based study of linear enamel thickness in the mesial cusp section of human molars: reevaluation of methodology and assessment of within-tooth, serial, and individual variation. Anthropological Science, 113(3), 273-289.

Swales, D. L. M. (2012). Life Stress: A Bio-cultural Investigation into the Later Anglo-Saxon Population of the Black Gate Cemetery (Doctoral dissertation, University of Sheffield).

Ungar, P. S., \& Hlusko, L. J. (2016). The evolutionary path of least resistance. Science, 353(6294), 29-30. 